\title{
Empowering Leadership and Individual Creativity: The Mediation Role of Psychological Empowerment in Facing Covid-19 Pandemic
}

\author{
Yuni SISWANTI ${ }^{1}$, Muafi MUAFI ${ }^{2}$
}

Received: August 01, 2020 Revised: October 05, 2020 Accepted: October 15, 2020

\begin{abstract}
This study tests and analyzes the influence of empowering leadership on employee creativity which is mediated by psychological empowerment. Researchers conduct survey method on state-owned bank employees (ABC Bank) in Pacitan, East Java, Indonesia. Purposive sampling is selected with Likert scale as measurement. The population of this study is 166 respondents, who are permanent employees of the ABC Bank. The data analysis technique used is SPSS 24. The results of this study find that: (1) there is an influence of empowering leadership on psychological empowerment, (2) there is an influence of empowering leadership on individual creativity, (3) there is an influence of psychological empowerment on individual creativity, and (4) the influence of empowering leadership on individual creativity is mediated by psychological empowerment. This study ignores other types of leadership. Further study is needed to examine other types of leadership besides empowering leadership. The level of analysis of this study is individual, so further study could examine empowering leadership conceptualized at the group level because followers will be influenced not only by the dyadic relationship with the leader, but also by the dynamics of the members of the empowered group. This study provides theoretical enrichment from the aspect of empowering leadership, especially at the individual level. Leaders can increase employee creativity by empowering them to do their jobs. Additionally, by creating a work environment that ensures employees feel empowered psychologically.
\end{abstract}

Keywords: Empowering Leadership, Psychological Empowerment, Individual Creativity

JEL Classification Code: L1, L2, L25, E24

\section{Introduction}

Lately, we have experienced turbulent environmental conditions, increased competition, and unpredictable technological changes, coupled with the COVID-19 pandemic that occurred suddenly on a world scale and its enormous consequences for the sustainability of all businesses. Those conditions require managers to realize that they must encourage employees to become creative (Amabile,

${ }^{1}$ First Author. Department of Management, Business and Economic Faculty, Universitas Pembangunan Nasional "Veteran" Yogyakarta, Indonesia. Email: yuni.siswanti@upnyk.ac.id

${ }^{2}$ Corresponding Author. Professor, Department of Management, Business and Economics Faculty, Universitas Islam Indonesia [Postal Address: Jl. SWK Ringroad Utara Condong Catur, Yogyakarta, 55283, Indonesia] Email: muafi@uii.ac.id

(c) Copyright: The Author(s)

This is an Open Access article distributed under the terms of the Creative Commons Attribution Non-Commercial License (https://creativecommons.org/licenses/by-nc/4.0/) which permits unrestricted non-commercial use, distribution, and reproduction in any medium, provided the original work is properly cited.
1988; Shalley \& Gilson, 2004; Dnishev \& Alzhanova, 2016). Scientific evidence shows that employee creativity fundamentally contributes to innovation, effectiveness, and organizational survival (Shalley et al., 2004). Creativity refers to novelty products and useful ideas from a person or group of individuals working together (Amabile, 1988; Madjar et al., 2002; Shalley et al., 2000; Zhou and Shalley, 2003). Managers need to support and promote creativity in organizations, because they are the most knowledgeable individuals and have a major influence on the group which brings forth creativity (Shalley and Gilson, 2004). Although a number of studies have examined the impact of leadership on creativity, this study mostly focuses on leader support issues (Amabile et al., 2004) and member-leader exchanges (Tran et al., 2020; Tierney et al., 1999).

Recently, researchers have begun investigating broader reciprocity based theory of membership behavior, such as transformational leadership theory and they obtain mixed results (Tierney, 2008). Research to explore creativity is scarce, so there is a suggestion that experts should have greater efforts on empowering leadership approaches that 
can optimize employee creativity (Mumford et al., 2002; Tierney, 2008). Empowering leadership involves sharing power to increase employee motivation and investment in their work (Kirkman \& Rosen, 1997, 1999; Thomas \& Velthouse, 1990; HA, 2020). It is the main reason to study empowering leadership and its influence on creativity (Amabile, 1988; Amabile et al., 1996; Amabile et al., 2004; Thomas \& Velthouse, 1990). Therefore, the main objective of this study is to examine the influence of empowering leadership and psychological empowerment on creativity.

Zhang and Bartol (2010) state that empowering the leadership has a positive influence on psychological empowerment, which in turn has a positive influence on intrinsic motivation and involvement of the creative process. Intrinsic motivation has a positive influence on the involvement of the creative process. Creative process involvement is positively related to employee creativity. Intrinsic motivation is also positively related to employee creativity.

Empowering leaders will support an individual's readiness to change, but previous studies have shown different results. While some researchers claim that empowering leaders support individual readiness for change (Holten \& Brenner, 2015; Muafi et al., 2019; Yin et al., 2017; Dong et al., 2017), there are others which claim otherwise as well. This study is therefore, important to be conducted because:

1. Empowering leaders is not sufficient to increase individual readiness to change (Stewart et al., 2010; Meng et al., 2016; Yin, et al., 2017; Zhao \& Lee., 2019; Lee et al., 2018). Other mechanisms are also needed to be the main drivers of changing individual readiness and includes consequences or implementation of empowering leadership.

2. Studies on empowering leaders at the Asian level are still limited, especially related to increment in individual creativity. Fong and Snape (2015) shows that empowering leader directly influence the employee's tendency to engage in creative processes, because leaders help followers to gain self-confidence, emphasize the importance of their leadership, work process, and provide freedom to conduct work. As a result, an employee becomes more involved in his work, incorporating processes that lead to creative results.

3. To conduct studies on empowering leaders in different settings, especially on their influence on psychological empowerment, is important, because empowering leaders has a strong positive influence on the psychological strength of employees, when the identity of employee empowerment role is high. When the psychological empowerment process is high, it will influence the creative process involvement (Lee et al., 2018).

4. Employee creative behavior is urgently needed, especially in the Covid-19 pandemic era so that the organization survives in midst of fierce competition.

\section{Literature Review and Hypothesis Development}

\subsection{Empowering Leadership and Psychological Empowerment}

Empowering leadership is defined as a situation where a leader contributes power, autonomy, motivation, and other work privileges among followers (Ahearne et al., 2005; Zhang \& Bartol, 2010; Sims et al., 2009; Muafi et al., 2019). Martin et al., (2013) argue that the characteristic of empowering leadership behavior facilitates autonomy and competence among the members. The high level of autonomy and competence increase members' intrinsic motivation and produce more proactive behavior (Wang et al., 2017; Lee \& Ding, 2020).

According to Conger and Kanungo (1988) and Thomas and Velthouse (1990), psychological empowerment as an intrinsic form of motivation, is manifested in four cognitions that reflect an individual's orientation to his job role. Psychological empowerment is conceptualized as a psychological state that shows a series of individual cognitions or experiences. Conger and Kanungo (1988) define psychological empowerment as a process of enhancing an employee's self-efficacy through identifying conditions that foster a sense of empowerment through the transfer of formal organizational practices and informal techniques to provide reliable information. Conger and Kanungo (1988), Thomas and Velthouse (1990), and Spreitzer (1995) define power processes or psychological conditions manifested in four cognitions, namely, meaning, competence, selfdetermination, and impact. These four cognitions have been found to contribute positively to psychological empowerment (Seibert et al., 2011).

Zhang and Bartol (2010) argue that leaders differentiate subordinates in the degree to which they are empowered. Leader-member exchange theory shows that dyadic exchange relationship is formed based on personal relationships, compatibility, and follower characteristics (Dansereau et al., 1975). According to Sherony and Green (2002), followers are divided into inner and outer groups, along with a favorite group which gets the leader's attention. It helps them create meaning out of their work experience and link this to the overall group's goals (Nielsen \& Daniels, 2012). Members in the group have more positive exchanges with their leaders, tend to enjoy the respect and trust of the leader, which leads to grant of greater autonomy (Graen \& Uhl-Bien, 1995). Yukl and Fu (1999) find that managers delegated more opportunities to subordinates who were competent, shared their task objectives, and had the advantage of exchange relationships as well as a longer tenure. 
Apart from an individual level perspective, empowering leadership has also been conceptualized at the group level. This shows that the leader's behavior can be considered as a stimulus by subordinates. Members judge their leader based not only on how the leader personally behaves with them individually, but also on the leader's behavior towards the group as a whole. Empowering leadership at group-level can explain differences in employee outcomes, which is explained by empowering leadership at the individual level, because followers of the empowering leader will be influenced not only by the dyadic relationship with the leader, but also by the dynamics of the leader with the existing members of the empowered group (Srivastava et al., 2006). According to the social influence theory (Salancik \& Pfeffer, 1978), the group develops similar perceptions and attitudes, due to their regular interactions and sharing of experiences and information with the leader. It will lead to the development of norms and habits about behavior (Hausknecht et al., 2008). Thus, individuals can be influenced by the way their colleagues respond to empowering leadership, giving rise to group-level effects. Previous studies have examined that empowering leadership process influences attitudes and behavior, conducted at the individual level, team level or across levels (team to individual) (Chen et al., 2011; Srivastava et al., 2006; Zhang \& Bartol, 2010).

$\boldsymbol{H}_{\mathbf{H}}$ : Empowering leadership has a positive influence on psychological empowerment.

\subsection{Empowering Leadership and Individual Creativity}

Zhang and Bartol (2010) argue that leaders differentiate subordinates in the degree to which they are empowered. It builds on the insightful leader-member exchange (LMX) theory, which suggests that leaders adapt their behavior according to the characteristics of individuals. The use of the term 'differentiated leadership' refers to the extent of a leader's role, in various leadership levels, from one which focuses on individual behavior to individual group members followers (Dansereau et al., 1975; Nielsen \& Daniels, 2012; Wu et al., 2010; Tran et al., 2020; Nguyen, 2020). It will directly influence the quality of individual exchanges with the leader. Leader-member exchange theory suggests that dydic exchange is formed based on personal relationships, compatibility, and follower characteristics (Dansereau et al., 1975). Followers are divided into inner and outer groups (Sherony \& Green, 2002). The inner group is a favorite group that gets the leader's attention. It helps them to create meaning from their work experience (Nielsen \& Daniels, 2012). Inner group members have more positive exchanges with their leaders and tend to enjoy the respect and trust of the leader, therefore, they grant greater autonomy (Graen \&
Uhl-Bien, 1995). It shows that empowering leadership can be seen as a part of the leader's input into positive exchanges, differentiated by membership in the group.

Yukl and $\mathrm{Fu}$ (1999) find that managers delegate opportunities to subordinates who they perceive as competent, willing to share their task objectives, and have advantageous exchange relationships, and longer tenure. An empowering leader must provide appropriate autonomy and control, positive informational feedback, set inspiring and/or meaningful goals and facilitate the development of employee skills, so that it promotes employee feelings of self-determination and personal initiative at work which has an impact on creativity level increment (Conger \& Kanungo, 1988; Oldham \& Cummings, 1996). Aburuman (2016), Özarall (2015), Zhang and Bartol (2010) and Zhang and Zhou (2014) find that empowering leadership is an important determinant of employee creativity.

$\boldsymbol{H}_{2}$ : Empowering leadership has a positive influence on individual creativity.

\subsection{Psychological Empowerment and Individual Creativity}

When employees have a certain degree of autonomy and an idea about what is expected of their behavior, they tend to focus on ideas or problems longer and more persistent (Deci \& Ryan, 1991; Spreitzer, 1995). In creativity literature, participation in decision making and the perception of autonomy are important antecedents for creative outcomes (Amabile, 1988; Amabile et al., 2004). A sense of ownership and control over their own work may have positive results, so employees should be encouraged to develop creative ideas for solving problems, stimulating taking risks, exploring new cognitive pathways, and playing with ideas. Çekmecelioglu and Özbag (2014) find that psychological empowerment has a positive and significant influence on individual creativity.

$\boldsymbol{H}_{3}:$ Psychological empowerment has a positive influence on individual creativity.

$\boldsymbol{H}_{4}:$ Empowering leadership influences individual creativity mediated by psychological empowerment.

\section{Research Methods}

This study conducted through a survey and involved all state-owned bank employees in Pacitan, East Java, Indonesia (ABC Bank). All populations included in the sample met the purposive sampling criteria that is to be permanent employees at the bank. Researchers distributed questionnaires by visiting the bank directly according to the schedule determined by the bank. From the 185 questionnaires distributed, 166 were completely filled in, post which they are being processed and 
analyzed. This study uses 3 variables, namely, empowering leadership, psychological empowerment, and individual creativity. Indicators / questionnaire items refer to:

1. Empowering leadership (EL) using the ELQ instrument that consists of 38 items which are adopted from Arnold et al., (2000).

2. Psychological empowerment (PE) is measured at the individual level and consists of 27 items which are adopted from Gruys and Sackett, 2003.

3. Individual creativity (IC) consists of 13 items, which are adopted from Tierney et al., (1999).

All instruments are measured by 7-point Likert scale (scale $1=$ strongly disagree to scale $6=$ strongly agree). The gradual regression method from Baron and Kenny (1986) model is used in this study with the SPSS 24 statistical technique. The results of the validity and reliability tests conclude that all items and variables are valid and reliable.

\section{Results}

\subsection{Respondent Description}

Based on Table 1, it is known that majority of $\mathrm{ABC}$ bank employees i.e., $33 \%$, are between the ages of 31 to 40 . Majority of the respondents, i.e., 52\%, are female. Majority of employees have bachelor's degree, and comprises of 103 people forming $62 \%$ of the people surveyed. The longest working period is 1 to 10 years which forms $46 \%$ of the people, and most of the respondents are married i.e., $92 \%$ are married.

\subsection{Hypothesis Testing}

The results of the gradual regression test in this study are as shown in Table 2. Table 2 shows that the leadership empowerment variable has $t$ significance value of 0.000 $<0.05$. This means that leadership empowerment has a positive and significant influence on employee performance at Bank $\mathrm{ABC}$, which means that $\mathrm{H} 1$ is supported. Additionally, since the leadership empowerment variable has $\mathrm{t}$ significance value of $0.000<0.05$ and $\mathrm{R}$ Square value is 0.244 , it also means that leadership empowerment has a positive and significant influence on individual creativity of ABC Bank employees, which means $\mathrm{H} 2$ is supported.

Table 2 shows that the psychological empowerment variable has $t$ significance value of $0.000<0.05$. This means that psychological empowerment has a positive and significant influence on individual creativity at Bank ABC, which means that $\mathrm{H} 3$ is supported. From Table 2, it is known that the influence of leadership empowerment on individual creativity mediated by psychological empowerment is positive and significant. The $t$ significance value is $0.007<0.05$ and $R$ Square is 0.278 . The R Square in the mediation test $(0.278)$ has seen an increase from the R Square of the direct influence of leadership that empowers individual creativity (0.244). It can be concluded that psychological empowerment mediates the influence of empowering leadership on individual creativity at Bank $\mathrm{ABC}$ (H4 supported). The results of this study indicate the role of psychological empowerment as a partial mediating variable, because there is a significant direct influence of empowering leadership on individual creativity.

Table 1: Respondent Profile

\begin{tabular}{|l|l|c|c|}
\hline Profile & \multicolumn{1}{|c|}{ Descriptions } & Amount & Percentage \\
\hline \multirow{4}{*}{ Age } & $21-30$ years old & 40 & 0.24 \\
\cline { 2 - 4 } & $31-40$ years old & 55 & 0.33 \\
\cline { 2 - 4 } & $41-50$ years old & 53 & 0.32 \\
\cline { 2 - 4 } & $>50$ years old & 18 & 0.11 \\
\hline \multirow{3}{*}{ Gender } & Man & 80 & 0.48 \\
\cline { 2 - 4 } & Woman & 86 & 0.52 \\
\hline \multirow{3}{*}{ Last education } & Bachelor degree & 103 & 0.62 \\
\cline { 2 - 4 } & Master degree & 63 & 0.38 \\
\hline \multirow{2}{*}{ Length of working } & $1-10$ years old & 76 & 0.46 \\
\hline \multirow{3}{*}{} & $11-20$ years old & 48 & 0.29 \\
\hline \multirow{2}{*}{ Marital status } & $21-30$ years old & 33 & 0.20 \\
\hline & $>30$ years old & 9 & 0.05 \\
\hline & Single & 18 & 0.08 \\
\hline & Married & 148 & 0.92 \\
\hline
\end{tabular}


Table 2: Gradual Regression Test

\begin{tabular}{|l|c|c|c|c|c|c|}
\hline & R Square & B & S.E & t & P & Hypotheses \\
\hline $\mathrm{EL} \rightarrow \mathrm{PE}$ & .309 & .672 & .078 & 8.566 & .000 & H1: supported \\
\hline $\mathrm{EL} \rightarrow \mathrm{IC}$ & .244 & .702 & 7.276 & 7.276 & .000 & H2: supported \\
\hline $\mathrm{PE} \rightarrow \mathrm{IC}$ & .182 & .502 & .083 & 6.047 & .000 & H3: supported \\
\hline $\mathrm{EL} \rightarrow \mathrm{PE} \rightarrow \mathrm{IC}$ & .278 & .259 & .094 & 2.753 & .007 & H4: supported \\
\hline
\end{tabular}

\section{Discussion}

Hypothesis 1 which states that empowering leadership has a positive influence on psychological empowerment is supported. It is also supported by Chen et al., 2011, Srivastava et al., 2006 and Zhang and Bartol, 2010. A situation in which a leader contributes power, autonomy, motivation, and other job privileges among followers can increase members' intrinsic motivation and can produce more proactive behavior (Wang et al., 2017; Lee \& Ding, 2020). When an employee has a certain degree of autonomy and shape about what he wants through his behavior, employees tend to focus on longer and more persistent ideas or problems (Deci \& Ryan, 1991; Spreitzer, 1995). Individuals who have persistence and focus on problem solving manifest psychological empowerment. This happens to ABC bank which has a large number of employees and seek autonomy at work from their leader. Since empowering leadership is aimed specifically at empowering employees, the focus of this study is individual psychological empowerment as a mediator in relation to employee attitudes and outcomes. (Ahearne et al., 2005; Arnold et al., 2000), However, Zhang, et al., (2009) show group models or empowering leadership at the individual level as an antecedent of individual outcomes, with individual level mediators, risk mingled mediation in groups and between groups of effects. They recommend procedure to differentiate effects between groups and within groups.

Hypothesis 2 which states that empowering leadership has a positive influence on individual creativity is supported. The results of this study support Yukl and Fu (1999), Conger and Kanungo (1988), Zhang and Bartol (2010) and Zhang, et al., (2018). Without psychological empowerment, wrong behaviors and attitudes may arise from the empowered person and lead to negative outcomes. Çekmecelioğlu and Özbağ (2014) empirically investigated the impact of psychological empowerment including four cognitions namely, competence, impact, self-determination, and meaningfulness on individual creativity. The result shows that psychological empowerment has a significant impact on individual creativity. Employees will be more creative and work hard when they think their work means something to them. Competence and impact have a positive relationship with individual creativity. Other studies also contribute to supporting the role of psychological empowerment mediators as well as the role of psychological empowerment as a determinant of employee performance (Raub \& Rober, 2010; De Klerk \& Stander, 2014; Namasivayam et al., 2014; Fong \& Snape, 2015; Özarall, 2015). This has also been experienced by ABC Bank employees in facing Covid 19 pandemic, while trying to consider their work more meaningful, and has been accompanied by increased selfcompetence, awareness of self-determination, which has an impact on the creativity of employees.

Hypothesis 3 which states that psychological empowerment has a positive influence on individual creativity is supported. The results of this study support studies by Amabile, 1988 and Amabile et al., 2004. When leaders conduct psychological empowerment for employees by providing more delegation opportunities to employees who are competent, it will facilitate employee skill development thereby leading to employees taking initiative in the workplace, which has an impact on increasing the creativity level of members. This is also adopted by the leader of the ABC bank to further the process of psychological empowerment for its members. The success of the psychological empowerment can be seen in members' work behavior that is increasingly creative. This creative behavior is in the form of service to customers with more varied methods, more effective service time, and more optimal use of digital technology according to customer needs.

Hypothesis 4 which states that psychological empowerment mediates the influence of empowering leadership on individual creativity is supported. The results of this study show when empowering leadership increases, it increases the psychological empowerment of employees (Chen et al., 2011; Srivastava et al., 2006; Zhang \& Bartol, 2010). Employees who feel high in psychological empowerment (characterized by competence, impact, self-determination, and meaningful in conduct their work) will have creativity increment. The creativity of $A B C$ bank employees is characterized by the ability to use their knowledge and make leaps that allow them to see things in new ways. Creativity enables new discoveries in science and technology, satisfying the needs of customers and other stakeholders. 


\section{Contributions}

The practical contribution of this study is leaders can enhance employee creativity by empowering them to do their jobs. In addition, leaders should create work environment such that employees feel empowered psychologically. To increase creativity, leaders must increase employees' confidence in their ability to perform tasks, make them feel that their work is meaningful, encourage them to participate in the decision-making process, and inspire them to work independently. On the other hand, the leader must provide support and access to organizational resources. By doing so, it is hoped that employees will be more creative and achieve optimal performance in the long term. The theoretical contribution of this study is to provide theoretical enrichment from empowering leadership aspect, especially at the individual level because individual studies in Asia are still limited.

\section{Limitation and Recommendation}

This study only uses one company as an object, so the results cannot be generalized. The population is very limited. Further study should develop its object in manufacturing companies, service companies, and non-profit organizations, by increasing the number of population. Data is collected is cross sectional (one time), thus, it may be biased because leaders and employees at different times may show different behaviours that might affect the way they respond to the questionnaire. Therefore, further study should be done in time series method. This method can see the consistency of respondents in answering the questionnaire, so that the results are stronger. This study only integrates empowering leadership and psychological empowerment as independent variables that influence employee creativity and ignores other types of leadership. Further study should examine different types of leadership.

The level of analysis of this study is individual, so that members can only see the leader's behavior towards members personally. Further study on empowering leadership should be conceptualized at the group level. Empowering leadership at the group level can explain the differences in employee outcomes explained at the individual level, because followers of the empowering leader will be influenced not only by the dyadic relationship with the leader, but also by the dynamics of the existence of members of the empowered group.

\section{References}

Aburuman, N. M. (2016). The impact of administrative empowerment on creativity improvement among the workers of Jordanian public administration institute. International Journal of Business and Social Science, 7(1), 182-190.
Ahearne, M., Mathieu, J., \& Rapp, A. (2005). To empower or not to empower your sales force? An empirical examination of the influence of leadership empowerment behavior on customer satisfaction and performance. Journal of Applied Psychology, 90(5), 945-960. https://doi.org/10.1037/0021-9010.90.5.945

Amabile, T. M. (1988). A model of creativity and innovation in organizations. Research in Organizational Behavior, 10(1), 123-167.

Amabile, T. M., Conti, R., Coon, H., Lazenby, J., \& Herron, M. (1996). Assessing the work environment for creativity. Academy of Management Journal, 39(5), 1154-1184. https:// doi.org/10.5465/256995

Amabile, T. M., Schatzel, E. A., Moneta, G. B., \& Kramer, S. J. (2004). Leader behaviors and the work environment for creativity: Perceived leader support. The Leadership Quarterly, 15(1), 5-32. https://doi.org/10.1016/j.leaqua.2003.12.003

Arnold, J. A., S. Arad, J. A. Rhoades \& F. Drasgow (2000). The empowering leadership questionnaire: The construction and validation of a new scale for measuring leader behaviors. Journal of Organizational Behavior, 21, 249-269. https://doi. org/10.1002/(SICI)1099-1379(200005)21:33.0.CO;2-\#

Baron, R. M., \& Kenny, D. A. (1986). The moderator-mediator variable distinction in social psychological research: Conceptual, strategic, and statistical considerations. Journal of Personality and Social Psychology, 51, 1173-1182. https://doi. org/10.1037//0022-3514.51.6.1173

Çekmecelioglu, H., \& Özbag, G. K. (2014). Linking psychological empowerment, individual creativity and firm innovativeness: A research on Turkish manufacturing industry. Business Management Dynamics, 3(10), 1-17.

Chen, G., Sharma, P. N., Edinger, S. K., Shapiro, D. L., \& Farh, J. L. (2011). Motivating and demotivating forces in teams: Crosslevel influences of empowering leadership and relationship conflict. Journal of Applied Psychology, 96(3), 541-555. https://doi.org/10.1037/a0021886

Conger, J. A., \& Kanungo, R. N. (1988). The empowerment process: Integrating theory and practice. Academy of Management Review, 13(3), 471-482. https://doi.org/10.2307/258093

Dansereau Jr, F., Graen, G., \& Haga, W. J. (1975). A vertical dyad linkage approach to leadership within formal organizations: A longitudinal investigation of the role making process. Organizational Behavior and Human Performance, 13(1), 4678. https://doi.org/10.1016/0030-5073(75)90005-7

De Klerk, S. \& Stander, M. W. (2014). Leadership empowerment behaviour, work engagement and turnover intention: The role of psychological empowerment. Journal of Positive Management, 5(3), 28- 45. https://doi.org/10.12775/JPM.2014.018

Deci, E. L., \& Ryan, R. M. (1991). A motivational approach to self: Integration in personality. In: R. A. Dienstbier (Ed.), Current theory and research in motivation (Vol. 38) (pp. 237-288). Nebraska Symposium on Motivation, 1990: Perspectives on motivation. University of Nebraska Press.

Dnishev, F., \& Alzhanova, F. (2016). Globalization of technological development and opportunities for national innovation systems 
of developing countries. Journal of Asian Finance, Economics and Business, 3(4), 67-79. https://doi.org/10.13106/jafeb.2016. vol3.no4.67

Dong, Y., Bartol, K. M., Zhang, Z. X., \& Li, C. (2017). Enhancing employee creativity via individual skill development and team knowledge sharing: Influences of dual-focused transformational leadership. Journal of Organizational Behavior, 38(3), 439-458. https://doi.org/10.1002/job.2134

Fong, K. H. \& Snape, E. (2015). Empowering leadership, psychological empowerment and employee outcomes: Testing a multi-level mediating model. British Journal of Management, 26, 126-138. https://doi.org/10.1111/1467-8551.12048

Graen, George B., \& Uhl-Bien, M. (1995). Relationship-based approach to leadership: Development of leader-member exchange (LMX) theory of leadership over 25 years: Applying a multi-level multi-domain perspective. The Leadership Quarterly. https://doi.org/10.1016/1048-9843(95)90036-5

Gruys, M. L., \& Sackett, P. R. (2003). Investigating the dimensionality of counterproductive work behavior. International Journal of Selection and Assessment, 11(1), 30-42. https://doi.org/10.1111/1468-2389.00224

Ha, V. D. (2020). The impacts of empowerment on the teamwork performance: Evidence from commercial banks in Vietnam. Journal of Asian Finance, Economics, and Business, 7(4), 267-273. https://doi.org/10.13106/jafeb.2020.vol7.no4.267

Hausknecht, J. P., Hiller, N. J., \& Vance, R. J. (2008). Work-unit absenteeism: Effects of satisfaction, commitment, labor market conditions, and time. Academy of Management Journal, 51(6), 1223-1245. https://doi.org/10.5465/amj.2008.35733022

Holten, A. L., \& Brenner, S. O. (2015). Leadership style and the process of organizational change. Leadership and Organization Development Journal. https://doi.org/10.1108/LODJ-11-20120155

Kirkman, B. L. \& Rosen, B. (1997) A model of work team empowerment. In: W. A. Pasmore \& R. W. Woodman (Eds.), Research in Organizational Change and Development (Vol. 10) (pp. 131-169).

Kirkman, B. L., \& Rosen, B. (1999). Beyond self-management: Antecedents and consequences of team empowerment. Academy of Management Journal. https://doi.org/10.2307/256874

Lee, A., Willis, S., \& Tian, A. W. (2018). Empowering leadership: A meta-analytic examination of incremental contribution, mediation, and moderation. Journal of Organizational Behavior, 39(3), 306-325. https://doi.org/10.1002/job.2220

Lee, M. C. C., \& Ding, A. Y. L. (2020). Comparing empowering, transformational, and transactional leadership on supervisory coaching and job performance: A multilevel perspective. PsyCh Journal. https://doi.org/10.1002/pchj.345

Madjar, N., Oldham, G. R., \& Pratt, M. G. (2002). There's no place like home? The contributions of work and nonwork creativity support to employees' creative performance. Academy of Management Journal, 45(4), 757-767. https://doi. org/10.2307/3069309
Martin, S. L., Liao, H., \& Campbell, E. M. (2013). Directive versus empowering leadership: A field experiment comparing impacts on task proficiency and proactivity. Academy of Management Journal, 56(5), 1372-1395. https://doi.org/10.5465/ amj.2011.0113

Meng, L., Jin, Y., \& Guo, J. (2016). Mediating and/or moderating roles of psychological empowerment. Applied Nursing Research, 30, 104-110. https://doi.org/10.1016/j.apnr.2015.11.010

Muafi., Fachrunnisa, O., Siswanti, Y., El Qadri, Z. M., \& Harjito, D. A. (2019). Empowering Leadership and Individual Readiness to Change: The Role of People Dimension and Work Method. Journal of the Knowledge Economy, 10(4), 1515-1535. https:// doi.org/10.1007/s13132-019-00618-Z

Mumford, M. D., Scott, G. M., Gaddis, B., \& Strange, J. M. (2002). Leading creative people: Orchestrating expertise and relationships. The Leadership Quarterly, 13(6), 705-750. https://doi.org/10.1016/S1048-9843(02)00158-3

Namasivayam, K., Guchait, P., \& Lei, P. (2014). The influence of leader empowering behaviors and employee psychological empowerment on customer satisfaction. International Journal of Contemporary Hospitality Management, 26(1), 69-84. https://doi.org/10.1108/IJCHM-11-2012-0218

Nielsen, K., \& Daniels, K. (2012). Does shared and differentiated transformational leadership predict followers' working conditions and well-being?. The Leadership Quarterly, 23(3), 383-397. https://doi.org/10.1016/j.leaqua.2011.09.001

Nguyen, T. H. (2020). Impact of leader-member relationship quality on job satisfaction, innovation and operational performance: A case in Vietnam. Journal of Asian Finance, Economics, and Business, 7(6), 449-456. https://doi.org/10.13106/jafeb.2020. vol7.no6.449

Oldham, G. R., \& Cummings, A. (1996). Employee creativity: Personal and contextual factors at work. Academy of Management Journal, 39(3), 607-634. https://doi. org/10.2307/256657

Özarallı, N. (2015). Linking empowering leader to creativity: The moderating role of psychological (felt) empowerment. Procedia - Social and Behavioral Sciences, 181, 366-376. https://doi.org/10.1016/j.sbspro.2015.04.899

Raub, S. \& Rober, C. (2010). Differential effects of empowering leadership on in-role and extra-role employee behaviors: Exploring the role of psychological empowerment and power values. Human Relations, 63(11), 1743-1770. https://doi. org/10.1177/0018726710365092

Salancik, G. R., \& Pfeffer, J. (1978). A social information processing approach to job attitudes and task design. Administrative Science Quarterly, 224-253. https://doi.org/10.2307/2392563

Seibert, S. E., Wang, G., \& Courtright, S. H. (2011). Antecedents and consequences of psychological and team empowerment in organizations: A meta-analytic review. Journal of Applied Psychology, 96(5), 981. https://doi.org/10.1037/a0022676

Shalley, C. E., \& Gilson, L. L. (2004). What leaders need to know: A review of social and contextual factors that can foster or 
hinder creativity. The Leadership Quarterly, 15(1), 33-53. https://doi.org/10.1016/j.leaqua.2003.12.004

Shalley, C. E., Gilson, L. L., \& Blum, T. C. (2000). Matching creativity requirements and the work environment: Effects on satisfaction and intentions to leave. Academy of Management Journal, 43(2), 215-223. https://doi.org/10.2307/1556378

Shalley, C. E., Zhou, J., \& Oldham, G. R. (2004). The effects of personal and contextual characteristics on creativity: Where should we go from here?. Journal of Management, 30(6), 933958. https://doi.org/10.1016/j.jm.2004.06.007

Sherony, K. M., \& Green, S. G. (2002). Coworker exchange: Relationships between coworkers, leader-member exchange, and work attitudes. Journal of Applied Psychology, 87(3), 542556. https://doi.org/10.1037/0021-9010.87.3.542

Sims Jr, H. P., Faraj, S., \& Yun, S. (2009). When should a leader be directive or empowering? How to develop your own situational theory of leadership. Business Horizons, 52(2), 149-158. https://doi.org/10.1016/j.bushor.2008.10.002

Spreitzer, G. M. (1995). Psychological empowerment in the workplace: Dimensions, measurement, and validation. Academy of Management Journal, 38(5), 1442-1465. https:// doi.org/10.2307/256865

Srivastava, A., Bartol, K. M., \& Locke, E. A. (2006). Empowering leadership in management teams: Effects on knowledge sharing, efficacy, and performance. Academy of Management Journal, 49(6), 1239-1251. https://doi.org/10.5465/ AMJ.2006.23478718

Stewart, J. G., McNulty, R., Griffin, M. T. Q., \& Fitzpatrick, J. J. (2010). Psychological empowerment and structural empowerment among nurse practitioners. Journal of the American Academy of Nurse Practitioners, 22(1), 27-34. https://doi.org/10.1111/j.1745-7599.2009.00467.x

Thomas, K. W., \& Velthouse, B. A. (1990). Cognitive elements of empowerment: An "interpretive" model of intrinsic task motivation. Academy of Management Review, 15(4), 666-681. https://doi.org/10.2307/258687

Tierney, P. (2008). Leadership and employee creativity. Handbook of Organizational Creativity, 95123.

Tierney, P., Farmer, S. M., \& Graen, G. B. (1999). An examination of leadership and employee creativity: The relevance of traits and relationships. Personnel Psychology, 52(3), 591-620. https://doi.org/10.1111/j.1744-6570.1999.tb00173.x

Tran, D.-T., Lee, L.-Y., \& Nguyen, P.-T.., \& Sritittiratku, W. (2020). How Leader Characteristics and Leader Member Exchange
Lead to Social Capital and Job Performance. Journal of Asian Finance, Economics and Business, 7(1), 269-278. https://doi. org/10.13106/jafeb.2020.vol7.no1.269

Wang, H., Demerouti, E., \& Le Blanc, P. (2017). A job crafting perspective on empowering leadership and job performance. In: Academy of Management Proceedings (pp. 13785). Briarcliff Manor, NY: Academy of Management.

Wu, J. B., Tsui, A. S., \& Kinicki, A. J. (2010). Consequences of differentiated leadership in groups. Academy of Management Journal, 53(1), 90-106. https:/doi.org/10.5465/ AMJ.2010.48037079

Yin, K., Xing, L., Li, C., \& Guo, Y. (2017). Are empowered employees more proactive? The contingency of how they evaluate their leader. Frontiers in Psychology, 8, 1802-1816. https://doi.org/10.3389/fpsyg.2017.01802

Yukl, G., \& Fu, P. P. (1999). Determinants of delegation and consultation by managers. Journal of Organizational Behavior, 20(2), 219-232. https://doi.org/10.1002/(SICI)10991379(199903)20:2\%3C219::AID-JOB922\%3E3.0.CO;2-8

Zhang, S., Ke, X., Wang, X. H., \& Liu, J. (2018). Empowering leadership and employee creativity: A dual-mechanism perspective. Journal of Occupational and Organizational Psychology, 91(4), 896-917. https://doi.org/10.1111/joop.12219

Zhang, X., \& Bartol, K. M. (2010). Linking empowering leadership and employee creativity: The influence of psychological empowerment, intrinsic motivation, and creative process engagement. Academy of Management Journal, 53(1), 107-128. https://doi.org/10.5465/AMJ.2010.48037118

Zhang, X., \& Zhou, J. (2014). Empowering leadership, uncertainty avoidance, trust, and employee creativity: Interaction effects and a mediating mechanism. Organizational Behavior and Human Decision Processes, 124, 150-164. https://doi. org/10.1016/j.obhdp.2014.02.002

Zhang, Z., Zyphur, M. J., \& Preacher, K. J. (2009). Testing multilevel mediation using hierarchical linear models: Problems and solutions. Organizational Research Methods, 12(4), 695-719. https://doi.org/10.1177/1094428108327450

Zhao, H., \& Li, C. (2019). A computerized approach to understanding leadership research. The Leadership Quarterly, 30(4), 396-416. https://doi.org/10.1016/j.leaqua.2019.06.001

Zhou, J., \& Shalley, C. E. (2003). Research on employee creativity: A critical review and directions for future research. In: J. J. Martocchio \& G. R. Ferris (Eds.), Research in personnel and human resources management (Vol. 22) (pp. 165-217). 